\title{
Den dobbelte danske udenrigspolitik
}

\section{Torben Krogh}

Femte bind i det store værk om Dansk Udenrigspolitiks Historie dækker årene fra 1945 til 1972 og er en kompetent og interessevækkende fremstilling af den periode, der bragte Danmark ud af krigens tunge skygger, ind i NATO og frem til optagelsen i de Europæiske Fællesskaber

Thorsten Borring Olesen og Paul Villaume: I blokopdelingens tegn 1945-1972. Bind 5 i Dansk Udenrigspolitiks Historie. Gyldendal Leksikon, København 2005, 808 s.

Ord som dilemmaer, paradokser og dobbelthed trænger sig på, når dansk udenrigspolitik siden 1945 skal beskrives og analyseres. Ingen statsminister har sandsynligvis haft sådanne problemer tættere inde på livet end Hans Hedtoft, den socialdemokratiske leder af regeringen fra 1947 til 1950 og igen fra 1953 til hans tidlige død som 55-årig i 1955. I begyndelsen af 1950'erne talte han på den ene side om danskernes "sunde skepsis over for alle stormagter”, mens han på den anden side mindede om, at Danmark, såvel befolkning som politikere, af historiske årsager "i vor tænken er en af de mest sognegrænsebestemte nationer", og at det derfor gjaldt om at søge at "orientere os som verdensborgere".

Dette var udfordringen - nok hovedudfordringen - for dansk udenrigspolitik i perioden 1945-72, skriver Thorsten Borring Olesen og Paul Villaume i deres store og glimrende værk. De angiver, at de i vidt omfang bygger på hidtil ubenyttet dansk og udenlandsk arkivmateriale. Bogen byder da også på mange interessante oplysninger om baggrunde og processer i den udenrigspolitiske beslutningstagen. Men det bærende er trods alt en fint gennemført fasthol- 
den af de perspektiver, der ligger i Hedtofts betragtninger.

Umiddelbart kunne det være fristende at se disse 27 år som det store opbrud i den danske politik over for omverdenen. Men som forfatterne fremhæver, var forløbet betydelig mere kompliceret og sammensat. Nok havde slagordet "aldrig mere en 9. april" stærk gennemslagskraft i årene efter befrielsen. Men hvordan det kunne omsættes til en ændret udenrigs- og sikkerhedspolitik stod til gengæld ikke særlig klart for datidens politiske beslutningstagere. Ganske vist skete der især hos socialdemokraterne en markant nyorientering, når det gjaldt indretningen og omfanget af det danske militær. Men i hvilken ramme skulle en større forsvarsstyrke placeres i forhold til andre lande?

\section{Det nordiske forlis}

Spørgsmålet blev stadig mere påtrængende, efterhånden som den sovjetiske imperiemagt fremstod som stadigt mere truende. Det var lykkedes at få russerne til at trække sig tilbage fra Bornholm efter et lille års besættelse. Men det ændrede intet ved, at Sovjetunionen var blevet den nye dominerende militærmagt i Østersøen. Selv om Tyskland samtidig lå i ruiner, besat af de fire store allierede, herskede der fortsat en dyb mistillid til naboen i syd.

Det første svar fra Hedtoft-regeringen var sonderingen af det muli- ge i et skandinavisk forsvarsforbund. Forestillingen var, at Danmark igennem en sådan alliance, der ikke mindst i kraft af de betydelige svenske forsvarsressourcer ville fremstå som troværdig over for omverdenen, kunne bevare en placering som alliancefri mellem de to nye dominerende supermagter. Som forfatterne overbevisende gør rede for, var det først, da de nordiske forhandlinger kuldsejlede - ikke mindst på grund af Norges præference for den nye, store atlantiske mulighed - at den danske regering sammen med det solide parlamentariske flertal, der nu stod bag sikkerhedspolitikken, valgte at gå ind i forhandlinger om optagelse i NATO.

Denne beslutning, der blev truffet af Hedtoft med fast overbevisning, men uden glæde, kunne så opfattes som et afgørende nybrud i dansk udenrigs- og sikkerhedspolitik. For første gang kunne Danmark gå i direkte alliance med en stor beskyttende magt. Dermed var der også rent militært givet svar på spørgsmålet om, "hvad skal det nytte". De danske styrker skulle have en slagkraft så tilpas, at de kunne forsvare det nationale territorium, indtil der nåede allierede forstærkninger frem. Det var i hvert fald sådan, det blev fremstillet i samtiden.

Men som det fremgår af bogen, var bruddet alligevel ikke så konsekvent, som det kunne se ud. Villigheden til at gå ind i et kollektivt sikkerhedsarrangement var allerede 


\section{LITTERATUR Den dobbelte danske udenrigspolitik}

markeret ved medlemskabet af de Forende Nationer. Den danske regering havde i 1945 måttet presse hårdt på for at komme med i denne sammenslutning af krigens sejrherrer. Optagelsen var derfor en sejr for det danske diplomati, og FN blev i de første år opfattet som en alliance. Altså var der allerede her, efter de daværende beslutningstageres opfattelse, tale om en markant nyorientering. Der var sagt forvel til neutralitetspolitikken. Og da det så viste sig, at den stadigt ekskalerende konflikt mellem USA og Sovjetunionen lammede FN's funktioner som garant for medlemsstaternes sikkerhed, var det oplagt at søge ind under en mere troværdig paraply.

Men alliancen med USA, Storbritannien, Frankrig, Canada og en række mindre europæiske lande indebar i første omgang ikke nogen egentlig ændring i synet på de danske muligheder i international politik. Som Borring Olesen og Villaume skriver: "Uanset Hitler-Tysklands sammenbrud i 1945 levede elementer af det scavenianske og munchske syn imidlertid videre blandt de udenrigspolitiske beslutningstagere, især i de første 10-15 efterkrigsår, hvor skyggen fra den nye nabostormagt, Sovjetunionen, føltes mest påtrængende. Det gjaldt ikke mindst opfattelsen af småstatens begrænsede muligheder for selv at påvirke de store internationale spørgsmål, for eksempel afspejlet i stats- og udenrigsminister H.C. Hansens offentlige udtalelser i 1957-58 om, at mindre lande som Danmark ofte savnede "den historiske og politiske baggrund for at kunne bidrage til løsningen af de internationale, storpolitiske problemer, og at de derfor heller ikke kunne forventes at påtage sig et medansvar herfor."

Skyggen fra Sovjetunionen forsøgte Danmark ikke kun at besvare igennem medlemskabet af NATO. Regeringen og diplomatiet udfoldede betydelige bestræbelser på at overbevise magthaverne i Kreml om fraværet af enhver aggressiv hensigt i det danske valg af tilforhørsforhold.

Den grundlæggende amerikanske strategi, der byggede på afskækkelse som middel til at forhindre aggressioner fra østblokken, passede de skiftende danske regeringer fint. Men selv lagde de stor vægt på det begreb, der i begyndelsen kunne kaldes "ikke-provokation", men som senere udviklede sig til en mere aktiv og selvstændig afspændingspolitik.

\section{Dobbeltheden}

Lige fra sin indtræden i den atlantiske alliance var Danmark derfor en allieret med forbehold. Amerikanerne fik - eller rettere tog - det, de ville, i relation til baserne på Grønland. Men når det gjaldt det danske territorium satte de tre centrale NATO-partier hælene i. De afviste både a-våben - bortset fra Grønland - og forskellige forslag om stationering af flere tusinde allierede (ame- 
rikanske og britiske) tropper ved militære flyvestationer. Som forfatterne skriver, forsøgte beslutningstagerne at maksimere landets sikkerhed ved både at være loyal allieret og fordre nationale undtagelser.

Der var med andre ord helt fra begyndelsen en dobbelthed i den danske NATO-politik. Sovjetunionen blev opfattet som den store og dominerende trussel - det var "fjenden", der til tider henvendte sig med højst ubehagelige diplomatiske noter, som til gengæld blev besvaret med dansk fasthed. Men i det daglige var det ofte presset fra USA, der var mest ubehageligt for de danske beslutningstagere. Da disse forhandlinger var omgivet af ekstrem lukkethed, fik befolkningen - og for den sags skyld også det store fleretal af folketingsmedlemmer og de fleste ministre - kun en vag fornemmelse af, hvad der virkelig gik for sig.

Det hindrede dog ikke, at udenrigspolitik fra sidst i 1950'erne fik voksende betydning i offentligheden. Et kritisk folkeligt engagement kom til udtryk i kampagnen mod atomvåben, der kulminerede i begyndelsen af 1960'erne. Men engagementet blev fastholdt på områder som modstand mod europæisk kolonialisme, diktaturregimerne i det sydlige Europa og apartheid-styret i Sydafrika. Højdepunktet i den periode, der er dækket af dette bind, kom med den stadigt mere omfattende modstand mod USA's krig i Vietnam, Laos og Cambodia.

\section{"Småstatschauvinisme"}

Disse folkelige stemninger havde utvivlsomt betydning for den udenrigspolitiske ageren. Men også af egen drift begyndte beslutningstagerne fra omkring 1960 at føre en mere aktiv politik. Det skete ud fra en overbevisning om, at ud over den traditionelle balancegang mellem ikke-provokation og loyal alliancepolitik måtte udenrigspolitikken også bygge på et sæt af ideer og værdier, hentet dels fra de fundamentale menneskerettigheder dels fra Danmarks egne demokratiske erfaringer.

Også i disse bestræbelser lå der imidlertid et sikkerhedspolitisk aspekt. Når Danmark, især ved udenrigsminister Per Hækkerup fra 1962 til 1966, profilerede sig højt i FN på anti-apartheid-politikken, var det ikke kun ud fra idealistisk solidaritet med den undertrykte sorte befolkning. Det måtte også ses som et led i bestræbelserne på at bidrage til en styrket international retsorden. Og netop dette begreb må altid indgå som en central sikkerhedsdimention for enhver mindre, demokratisk sindet stat.

Men for nogle var denne nye prioritering et irritationsmoment. Amerikanerne ville $\mathrm{fx}$ have foretrukket, at danskerne havde holdt sig til H.C. Hansens mere ydmyge vurdering af småstatens begrænsede muligheder (selv om H.C. Hansen faktisk selv ved flere lejligheder afprøvede disse 


\section{LITTERATUR Den dobbelte danske udenrigspolitik}

grænser til det yderste). Som forfatterne skriver, førte det til amerikansk "kritik mod danskerne omkostningsfri ‘idealisme' og 'moralisme', som kun en ansvarsfri småstat, der synes at gøre svaghed til en dyd, kunne tillade sig, fordi de store vestlige magter påtog sig byden for Vestens 'tunge' sikkerhed." USA's ambassadør i Danmark fandt ligefrem i 1972 et nyt ord for fænomenet: "Småstatschauvinisme".

\section{Udenrigsøkonomien}

I forholdet til de venligtsindede store magter var der i den skildrede periode forskellige faser. Over for de hyppige problemer i forhold til USA søgte de danske beslutningstagere ofte bistand og ligefrem trøst hos briterne, dog med vekslende held. Trods alliancefællesskabet var omgangen med de store magter derfor stadig en betydelig udfordring for danske regeringer.

Det var også tilfældet for det lange, komplicerede og besværlige forløb, der førte frem til medlemskabet af EF fra 1. januar 1973. Forfatternes glimrende behandling af den udenrigsøkonomiske politik giver et godt overblik over den kolossale udvikling, der skete fra det lukkede, kontrollerede og afgrænsede økonomiske regime i de første år efter anden verdenskrig til den dynamik, der lå i de europæiske markedsdannelser.
Danmarks problem bestod $i$, at der var flere - EF såvel som "randstaterne" i EFTA. Udenrigsøkonomisk var det i klar dansk interesse, hvis alle landene i de to organisationer kunne samles i én. Selv det ville dog ikke fjerne et andet og rent politisk problem. I kraft af selve sin målsætning var EF et politisk orienteret projekt, der indebar markant afgivelse af national myndighed til de fælles institutioner. At Danmark også kunne have fordel af, at andre lande - ikke mindst de større - gjorde det samme, var stort set et fraværende aspekt i den hjemlige debat.

Under alle omstændigheder betød hele diskussionen om den europæiske politik, at spørgsmålet om suverænitet dukkede op som et nyt centralt begreb. Også det gør de to forfattere rede for på kompetent og informativ vis. Bogen er i det hele taget god til at få indsigt af og velegnet til at genopfriske hukommelsen. Det, der måske i dag kan fremstå som brugstykker, bliver sat ind i en sammenhæng. Dertil kommer et fint og utraditionelt billedvalg, fx et foto fra 1947 fra tyske flygtninges indkvartering i HIK's tennishal i Hellerup. Det fortæller både noget om tidens knaphed - og om, at den danske regerings klare målsætning var at få disse flygtninge sendt tilbage til Tyskland så hurtigt som muligt. 